\title{
Knowledge Study, Income Level and Socio-Culture of the Nutritional Status of toddler
}

\author{
${ }^{1}$ Marniati, ${ }^{2}$ Enda Silvia Putri, ${ }^{3}$ Susy Sriwahyuni, ${ }^{4}$ Khairunnas, ${ }^{5}$ Maiza Duana \\ ${ }^{1}$ Department of Public Health, Faculty of Public Health, Universitas Teuku Umar, Meulaboh, Indonesia \\ ${ }^{2}$ Department of Nutrition, Faculty of Public Health, Universitas Teuku Umar, Meulaboh, Indonesia \\ ${ }^{3}$ Department of Public Health, Faculty of Public Health, Universitas Teuku Umar, Meulaboh, Indonesia \\ ${ }^{4}$ Department of Nutrition, Faculty of Public Health, Universitas Teuku Umar, Meulaboh, Indonesia \\ ${ }^{5}$ Department of Public Health, Faculty of Public Health, Universitas Teuku Umar, Meulaboh, Indonesia \\ Coresponding author: Marniati, marniati@utu.ac.id
}

\begin{abstract}
Toddler Nutrition Status Is a state of balance or manifestation of nutrition in the form of certain variables. The high incidence of malnutrition in Suka Makmue Subdistrict is centered as the main target in improving nutrition. The objective is to analyze the Knowledge Study of Income and Social Culture Level of Toddler Nutrition status in Blang Muling Village, Suka Makmue Subdistrict, Nagan Raya Regency. This type of research is Analytical Surveys with cross-sectional approach. The total number of samples is 33 mothers of toddlers. Univariate and Bivariate analyzes were further tested with Chi Square. The results after a deeper study of the three variables have an influence on the nutritional status of children under five namely Knowledge (Pvalue 0,000 <a 0.05), income

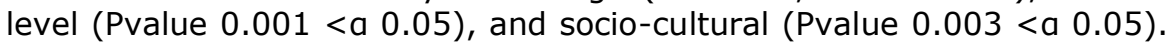
Suggestion Health workers should be more active in delivering information about the importance of the nutritional status of children under five.
\end{abstract}

\section{ARTICLE INFORMATION}

Submitted: $11 / 11 / 2020$

Revised: $11 / 11 / 2020$

Accepted: 28/11/2020

Published Online: 30/11/2020

Keywords:
Income Level
Knowledge
Social Culture
Toddler Nutrition Status

Keywords:

Knowledge

Toddler Nutrition Status

How to cite this article: Marniati, Putri, E. S., Sriwahyuni, S., Khairunnas, Duana, M. (2020). Knowledge Study, Income Level and Socio-Culture of the Nutritional Status of toddler. JNS : Journal of Nutrition Science, $1(2), 38-44$

\section{Introduction}

Malnutrition is a condition of malnutrition resulting from an imbalance of micro nutrients and macro nutrients. Parental diets can help create problems related to the nutritional status of toddlers. Giving children the right opportunity to consume food does not guarantee toddlers free from nutritional statistics. (Max, A. 2020). The toddler period is a very important period for future survival, therefore, health conditions, including the nutritional status of toddlers (Zogara, et al, 2020), need to be considered. Nutrition problems have a broad dimension if the consumption of nutrition in infants is not balanced it will result in nutritional status problems. (Fajriani, et al, 2020), The nutritional status of children under five can be used as an indicator of the nutritional state of the community. Nutritional status can be known through the nutritional prevalence of children aged 1-5 years because these age groups are most vulnerable to nutritional disorders (Gusrianti, at al 2020).

Toddler is a golden period to optimize brain growth and development, but it becomes a critical period if you don't get proper nutrition. Lack of mother's knowledge about toddler nutrition, eating problems, and diet can affect the nutritional status of toddlers (Hanim, B, 2020). Child development is the result of organ maturation, especially the central nervous system. Development occurs throughout life which consists of several stages, one of which is a toddler. Toddler age occurs from 1 to 3 years, where the development of children occurs very quickly and is a golden period in children. Success in mastering developmental tasks at the age of five requires a strong foundation during a

JNS: Journal of Nutrition Science 
period of growth and development. (Hayuningtyas et al, 2020).

The problem with nutritional status is that more nutrition is no less interesting in Indonesia, more than $4.5 \%$ of Indonesian children suffer from over nutrition (Rikesdas, 2013). According to Sedia Oetama (2010), nutrition is more defined as a state of imbalance between calorie consumption and energy needs where consumption is too excessive compared to energy needs or usage. Obesity is a term that is often used to refer to being overweight. The word obesity that comes from the Latin word means overeating, but currently obesity or overweight is defined as a disorder or disease characterized by excessive accumulation of fat tissue (Vinda, 2012). Everyone's needs for food are not the same, because the needs for various nutrients are also different. Knowledge, attitude, age, gender, type of work and other factors determine the needs of each person for food to become less protein energy (Syahmien, M, 2010).

The prevalence data for children under five with growth and development impairment was $28.7 \%$ and Indonesia was included in the third country with the highest prevalence in the Southeast Asian region (Risna, et al, 2020). In terms of region, more than $70 \%$ of cases of malnutrition in children are predominantly Asian, while $26 \%$ in Africa and $4 \%$ in Latin America and the Caribbean. Half of the 10.9 million cases of child deaths are dominated by cases of malnutrition. Because malnutrition can affect other diseases as well, such as measles and malaria (WHO, 2018). Based on Basic Health Research data (Rikesdas, 2018, the prevalence of malnutrition and malnutrition children in Indonesia reaches $19.6 \%$ and over $4.5 \%$ nutrition. This figure is increased compared to the 2018 Riskesdas data and $17.9 \%$ Riskesdas 2019 by $17.0 \%$. Among the 34 provinces, Aceh ranked 11th $(7.9 \%)$ for the malnutrition category, for the Acehnese lacking category ranked 7th $(18.4 \%)$ and for the category of over nutrition Aceh ranked 29th (2.9\%) in Indonesia (Indonesia Health Profile, 2018). Based on the Aceh Health Profile the number of nutritional problems under five years (toddlers) in Aceh Province continues to increase every year, the number of toddlers experiencing undernourishment reaches $24.8 \%$, in 2019 to 17. Of 23 districts in Aceh, Nagan Raya Regency occupies ranked 18th for nutritional problems in infants (Aceh Health Profile, 2018, 2019). Nagan Raya Regency has $11.7 \%$ underfives with 27 cases of malnutrition and 11 cases of malnutrition, all 38 cases total (profile of Nagan Raya Health Office, 2018).

From the recapitulation of the Cot Kuta Health Center in 2016, the number of toddlers in 2015 was 322 toddlers with 5 malnutrition categories $(1.5 \%)$ with a BGM of 1 toddler and over $25(7.7 \%)$ toddlers, while in 2016 there were 361 toddlers with the category of undernutrition as much as $10(2.8 \%)$ with BGM 3 toddlers, while overweight 41 $(11.36 \%)$ toddlers, the incidence of nutritional problems continues to increase from 2016 to 2017 in the work area of the Cot Kuta Health Center. Each village in the work area of the Cot Kuta Health Center has a high incidence of undernutrition and over nutrition, namely Blang Muling which is centered as the main target in improving nutrition (Cot Kuta Health Center, 2016). From the data there are 33 toddlers, with good nutrition category 15 $(45 \%)$, excess nutrition $12(36 \%)$ and malnutrition $6(18 \%)$ with BGM 2 people. (Profile of Blang Muling Village, 2018) The survey results many mothers who do not understand and do not know how to meet the nutritional status of their toddlers. They claim that they rarely monitor their toddler weight regularly due to insufficient income reasons, and rarely provide nutritious supplementary food for their toddlers, our social culture does not allow any food to be given to children under 5 years later some mothers also claim that their toddlers are very regularly consuming the food that is bad for us is good, they think that the more toddlers they consume and the more fats the toddler the healthier the child is. From the above problems, it is necessary to do research on the nutritional status of children under five in Blang Muling Village, Suka Makmue Subdistrict, Nagan Raya Regency.

\section{Literature review Knowledge}

Broadly speaking according to (Notoatmodjo, 2012) domain level of knowledge (cognitive) has six levels, including: knowing, understanding, using, describing, inferring and evaluating. The main characteristic in the level of knowledge is the memory of something he knows well through experience, learning, information received from others. 


\section{Income Level}

Revenues are gross inflows of economic benefits arising from the normal activities of an entity during a period, if the inflows result in an increase in equity that does not originate from investment contributions (Kieso et al. 2011).

\section{Socio-cultural}

Everything related to the values that exist in the community, in which there are statements about intellectual points and artistic values that can be made as a characteristic that exists in the community itself (Wawan, 2010).

\section{Nutrition Concept}

Nutrition is a chemical bond that is needed by the body to carry out its functions, namely producing energy, building, maintaining and regulating life processes (Almatsier, 2010). Handling of toddler nutrition problems can be done through the development of food products in the form of Moringa flour cookies and Moringa oatmeal flour cookies that are given to toddlers, and then assessed an increase in body weight and nutritional status. (Irwan, ar al, 2020).

\section{Toddler Nutrition Status}

Toddler nutritional status is a state of balance in the form of certain variables or the embodiment of nutrition in the form of certain variables (Supariasa, et al. 2012). Children under five are children who have reached the age of one year or more popular with the understanding of children under five years old (Muaris, H. 2006). According to Sutomo, A, (2010). Toddler is one of the periods of human age after infants with an age range starting from two to five years, or commonly used to calculate the age of 24-60 months. This age period is also referred to as preschool age (Aminuddin, 2014).

\section{Method}

This type of quantitative research is analytic with cross sectional approach (Notoatmodjo, 2012). This research was conducted in Blang Muling Village, Suka Makmue Subdistrict, Nagan Raya Regency in March 2019. The population of mothers under five is in Blang Muling village and the determination of the sample with the Total Sampling method is 33 mothers of toddlers. Univariate and bivariate analysis was further tested with chi-square

\section{Results}

Univariate analysis shows that the frequency distribution of Knowledge, Income Level and Social Culture has a significant influence on the nutritional status of toddlers where tilapia (Pvalue <a 0.05)

\section{Knowledge}

Review of Mother's Knowledge of Toddler Nutrition Status

\begin{tabular}{|l|c|c|c|c|c|c|c|c|}
\hline \multirow{2}{*}{$\begin{array}{l}\text { Knowlec } \\
\text { ge }\end{array}$} & \multicolumn{3}{|c|}{ Nutritional Status } & \multirow{2}{*}{ Total } & \multirow{2}{*}{\begin{tabular}{c}
$\mathrm{P}_{v}$ \\
alu \\
\cline { 2 - 7 }
\end{tabular}} & $\begin{array}{c}\mathrm{R} \\
\mathrm{P}\end{array}$ \\
\cline { 2 - 7 } & $\mathrm{n}$ & $\%$ & $\mathrm{n}$ & $\%$ & $\mathrm{f}$ & $\%$ & & \\
\hline Well & 12 & 85.7 & 2 & 14.3 & 14 & 100 & 0. & 3 \\
\hline $\begin{array}{l}\text { Not } \\
\text { Good }\end{array}$ & 3 & 15.8 & 16 & 84.2 & 19 & 100 & 00 & 2 \\
& & & & & & 0 & \\
\hline
\end{tabular}

Viewed from the table above there is a significant effect on nutritional status in infants, the (P.value $=0,000<a=0.05)$

Income Level

Study of income level on nutrition status in Toddlers

\begin{tabular}{|c|c|c|c|c|c|c|c|c|}
\hline \multirow{3}{*}{$\begin{array}{c}\text { Inco } \\
\text { me } \\
\text { Level }\end{array}$} & \multicolumn{4}{|c|}{ Nutritional Status } & \multirow{2}{*}{\multicolumn{2}{|c|}{ Total }} & \multirow{3}{*}{$\begin{array}{c}\mathrm{P}_{v} \\
a / u \\
e\end{array}$} & \multirow{3}{*}{$\mathrm{P}$} \\
\hline & & ell & Not & Good & & & & \\
\hline & $\mathrm{n}$ & $\%$ & $\mathrm{n}$ & $\%$ & $\mathrm{~F}$ & $\%$ & & \\
\hline High & 12 & 80.0 & 3 & 20.3 & 15 & 100 & 0. & 2 \\
\hline Low & 3 & 16.7 & 15 & 83.3 & 18 & 100 & $\begin{array}{c}00 \\
1\end{array}$ & 0 \\
\hline
\end{tabular}

The table above shows that there is an influence of income level on the nutritional status of children under five years of age (Pvalue $=0.001<a=0.05$

\section{Socio-cultural}

Socio-Cultural Study of Nutrition Status in Toddlers

\begin{tabular}{|c|c|c|c|c|c|c|c|c|}
\hline \multirow{3}{*}{$\begin{array}{c}\text { Socio } \\
- \\
\text { Cultu } \\
\text { ral }\end{array}$} & \multicolumn{4}{|c|}{ Nutritional Status } & \multirow{2}{*}{\multicolumn{2}{|c|}{ Total }} & \multirow{3}{*}{$\begin{array}{c}\mathrm{P}_{v} \\
\text { alu } \\
e\end{array}$} & \\
\hline & \multicolumn{2}{|c|}{ Well } & \multicolumn{2}{|c|}{ Not Good } & & & & \\
\hline & $n$ & $\%$ & $\mathrm{n}$ & $\%$ & $\mathrm{~F}$ & $\%$ & & \\
\hline $\begin{array}{l}\text { Supp } \\
\text { ort }\end{array}$ & 10 & 83.3 & 2 & 16.7 & 12 & 100 & $\begin{array}{l}0 . \\
00\end{array}$ & \\
\hline $\begin{array}{l}\text { Does } \\
\text { not } \\
\text { Supp } \\
\text { ort }\end{array}$ & 5 & 23.8 & 16 & 76.3 & 21 & 100 & 3 & \\
\hline
\end{tabular}

can be seen from the socio-cultural table there is an influence on the nutritional status of toddlers results $(P$.value $=0.003<$ a 0.05$)$ 


\section{Discussion}

\section{Review of mother's knowledge of nutritional status in infants}

Knowledge is everything that is known based on human experience itself and knowledge will increase according to the process of experience they experience. (Mubarak, 2018). Knowledge about the environment and knowledge efforts obtained by respondents came from various sources, such as books, mass media, education and education through relatives. New information about things from the mass media provides a new cognitive basis for the formation of knowledge (Notoatmodjo, 2012).

The results of the above research are supported by research by Maharani, S (2013) where the result is obtained that Pvalue = 0.001 so that there is a significant relationship between maternal knowledge and nutritional status of children under five. Mother is closely related to the nutritional status of children under five, where if someone has a good level of knowledge, it is probable that the nutritional status of toddlers will also be good. Then, (Intan, S, Y 2015) also proved that the results of the study with Pvalue $=0,000$ so that there is a close relationship between the knowledge of mothers and the nutritional status of children under five, where if a mother has good knowledge then the mother will have a good understanding of fulfillment nutrition for the toddler. According to the researchers' observations, poor mother's knowledge will affect the nutritional status of the toddler. because mothers do not understand in meeting nutritional needs. From the results of research that is influential is the mother's knowledge, in meeting the nutritional needs of toddlers because not until the nutrition of toddlers is not met

\section{Study the level of income on Nutrition Status in Toddlers}

The results obtained from Blang Muling Village, Suka Makmue Subdistrict, Nagan Raya Regency, out of 18 respondents who have a high income level, there are 15 people $(83.3 \%)$ who have poor nutritional status and there are 3 people $(16.7 \%)$ good nutritional status. While from 15 respondents who have high income levels, there are 12 people $(80.0 \%)$ solusi dari permasalahan tersebut adalah dengan menambah pengetahuan ibu dalam memenuhi kebutuhan gizi balita karena tidak sampai gizi balita tidak terpenuhi.
(20.3\%) who have poor nutritional status). The income level study on the nutritional status of children under five from table 4.2, which uses the chi square test obtained value (P.value $0.003<a 0.05$ ), social culture on the nutritional status of infants in Blang Muling Village, District of Suka Makmue, Regency Nagan Raya.

There is an influence of the level of family income on nutritional status in children under five with $p$ value $=0.050$, looking at factors that inhibit cross-sectoral collaboration between the health center and the village so that they can find solutions to increase family income, move the posyandu cadre to monitor the nutritional status of children under five. nutritional status of children under five years old, can be handled immediately and the use of home yards to produce food can also be used to improve family health (Kemen, 2014). In line with the study (Aminuddin, 2014) The level of income affects the nutritional status of children under five in the working area of the Rajabasa Indah Health Center in the city of Bandar Lampung in 2014 with a value $(p=$ 0.004). According to (Azhari, $\mathrm{H}, 2010$ ) revealed that the chi square test results obtained value of P.value 0.002 so that a significant influence the level of income in fulfilling food on the nutritional status of children. ThenTantri, J (2012) also said that there was a significant influence between the level of family income on the nutritional status of children under five with the results of the chi square test obtained $P$. value $=0.001 \mathrm{t}$. a person's income level is not sufficient to meet the nutritional needs of their toddlers. From the research results, a very basic problem is the level of community income because it is important create a surrounding environment as land for additional income

\section{Social and cultural studies of Nutritional Status in Toddlers}

Based on the results obtained by Blang Muling Village, Suka Makmue Subdistrict, Nagan Raya Regency, of the 21 respondents who had poor social culture there were 16 people $(76.3 \%)$ who had poor nutritional status and there were 5 people $(23.3 \%)$ who had good nutritional status. While from 18 respondents who have supportive social culture, there are 10 people $(83.3 \%)$ who have good nutritional status and there are 2 respondents (16.7\%) who have poor nutritional status). Sociocultural studies of nutritional status with the 
chi square test, the value of (P.value $0.003<a$ 0.05 ) social and cultural status regarding the nutritional status of children under five in Blang Muling Village, District of Makmue, Nagan Raya Regency.

Society has a culture that includes rules, norms, outlook on life which are used as a reference in regulating the culture of community life. The socio-cultural background in Blang Muling Village, Suka Makmue Subdistrict, Nagan Raya Regency is the Acehnese and Javanese people. Here patrilineal lineage patterns then in family customs, the role of husband / father is very influential. the father / husband as the head of the household is an intermediary in the determination of fate including those who control the economic resources of the family (Sampurno, 2020). Culture influences malnutrition such as the prohibition of eating certain things for adherents of a religion and certain norms adopted by the local community. This pattern of habits regarding a society and the food habits it follows, develops around the meaning of food and the use of suitable food. This cultural pattern affects the types of food that will be produced, processed, distributed, prepared, served (Mubarak, 2018). The results of socio-cultural observations are less supportive of the possibility of poor gizibal status, this can be seen from the results of research because a person's social culture that does not meet the nutritional needs of toddlers will continue. not good. From the results of research, it is important to always consider social and cultural considerations. In order to create a sense of caring to provide nutrition for toddlers. in a social and cultural way that can improve toddler nutrition.

\section{Conclusion}

The conclusion of the Knowledge study was most influential ( $p=0,000 ;$ OR $=3,200 ; 95 \%$ $C I)$. Income Level $(P=0.001)$, and Social Culture $(P=0.003)$ on Nutritional Status of Toddlers in Blang Muling Village, District of Suka Makmue, Nagan Raya Regency

\section{Suggestion}

Health workers should be more active in delivering information about the importance of the nutritional status of toddlers to mothers, so that mothers are more active in overcoming family nutrition in order to fulfill their toddler nutrition.

\section{References}

Almatsier, S., 2010.Prinsip Dasar Ilmu Gizi, Jakarta: PT Gramedia Pustaka Utama.

Aminuddi, 2014 Faktor Yang Mempengaruhi Status Gizi Pada Balita Usia 1-4 Tahun Di Wilayah Kerja Puskesmas Rajabasa Indah Kota Bandar Lampung Tahun 2014, Jurnal Ilmu Kedokterandan Kesehatan, Vol 3, No 1 (2016): Volume 3 Nomor 1

Azhari, Hidayati dan Masdawati, 2010. Hubungan Sikap dan Tindakan Ibu dalam Pemenuhan Asupan Makanan dengan Status Gizi pada Balita di Puskesmas Belawa Kabupaten Wajo. Jurnal Ilmiah. Vol. 1 No 2. Politeknik Kesehatan Makassar.

Fajriani, F., Aritonang, E. Y., \& Nasution, Z. (2020). Hubungan Pengetahuan, Sikap dan Tindakan Gizi Seimbang Keluarga dengan Status Gizi Anak Balita Usia 2-5 Tahun. Jurnal IImu Kesehatan Masyarakat, 9(01), 1-11. https://doi.org/10.33221/jikm.v9i01.470

Fitriani, 2011.Perilaku Manusia. Salemba Medika, Jakarta.

Gusrianti, G., Azkha, N., \& Bachtiar, H. (2020). Analisis Faktor yang Berhubungan dengan Status Gizi Balita di Kelurahan Limau Manis Selatan Wilayah Kerja Puskesmas Pauh Kota Padang. Jurnal Kesehatan Andalas, 8(4). https://doi.org/10.25077/jka.v8i4.1126

Hanim, B. (2020). Faktor Yang Memengaruhi Status Gizi Balita Di Wilayah Kerja Puskesmas Sidomulyo Kota Pekanbaru. JOMIS (Journal of Midwifery Science), 4(1), 15-24. https://doi.org/10.36341/jomis.v4i1.1118

Hayuningtyas, R. D., Laila, S. F. N., \& Nurwijayanti, N. (2020). Analysis of Factors Affecting the Development of Children of Toddler Ages Assessed from History of Infection Diseases, Nutritional Status and Psychosocial Stimulation in Ponorogo Regency. Journal for Quality in Public Health, 3(2), 341-347. https://doi.org/10.30994/jqph.v3i2.82 
Hidayah, N., \& Marwan, M. (2020). Upaya Pemberdayaan Masyarakat Dalam Menciptakan Generasi Milenial Sadar Gizi Yang Bebas Stunting Melalui Kegiatan 1000 HPK. Journal of Community Engagement in Health, 3(1), 86-93. https://doi.org/10.30994/jceh.v3i1.41

Hungu, 2007.Demografi Kesehatan Indonesia.Grasindo. Jakarta.

Intan, Susanti dan Yuliana.2015. Hubungan Perilaku Ibu dengan Status Gizi Anak Balita di Wilayah Kerja Puskesmas Nanggalo Padang. Jurnal Kesehatan Andalas. Vol. 4 No.1: 37-52.

Irwan, Z., Salim, A., \& Adam, A. (2020). Pemberian cookies tepung daun dan biji kelor terhadap berat badan dan status gizi anak balita di wilayah kerja Puskesmas Tampa Padang. AcTion: Aceh Nutrition Journal, 5(1), 45. https://doi.org/10.30867/action.v5i1.198

Jumrah Sudirman, Sumarni Mawang , Khalidatul Khair Anwar3, Hijrah, (2020). Analisis Status Gizi Ibu Hamil berdasarkan Faktor Sosial Budaya di Wilayah Kerja Puskesmas Antang Perumnas, Makassar, Sulawesi Selatan Journal of Healthcare Technology and Medicine Vol. 6 No. 1 April 2020 Universitas Ubudiyah Indonesia eISSN: 2615-109X

Khairunnas, K., Husna, A., \& Marniati, M. (2020). The Relationship of SocioEconomic with Nutritional Status in Toddlers in Meureubo Sub-District West Aceh Regency. Journal of Nutrition Science, 1(1), 6-10.

Khandelwal, N., Mandliya, J., Nigam, K., Patil, V., Mathur, A., \& Pathak, A. (2020). Determinants of motor, language, cognitive, and global developmental delay in children with complicated severe acute malnutrition at the time of discharge: An observational study from Central India. PLOS ONE, 15(6). http://doi.org/10.1371/journal.pone.0233 949

Klemen, 2014, Faktor-Faktor Yang Mempengaruhi Status Gizi Baik Dan Gizi Kurang Pada Balita Di Wilayah Kerja
Puskesmas Payo Selincah Kota Jambi Tahun 2014, Vol 4 No 1 (2015): Vol 4 No 1 (2015): Vol 4 No 1 (2015): Scientia Journal

Kieso, dkk.2011. Perilaku Kesehatan.Rineka Cipta Jakarta

Kubuga, C. K., Kennedy, G., \& Song, W. O. (2020). Food-based indicators are related to iron and iodine deficiencies of mothertoddler dyads during the lean season in northern Ghana. British Journal of Nutrition, 124(1), 92-101. https://doi.org/10.1017/S0007114520000 604

Maharani dan Sahara, 2013. Hubungan Pengetahuan dan Sikap Ibu dengan Status Gizi Balita di Desa Karangsono Kecamatan Kwadungan Kabupaten Ngawi. Jurnal Kebidanan Padjadjaran. Vol 2. No 5 : 4756.

Maksum, A. (2020). The Effect of Eating Food Patterns with Nutritional Status of Age 12 - 24 Months in The Working Area of Pademawu Pademawu District, Pademawu District, Pamekasan District. Journal of Public Health Science Research, 1(1), 19. https://doi.org/10.30587/jphsr.v1i1.1182

Merita, M., Sari, M. T., \& Hesty, H. (2017). Merita, M., Sari, M. T., \& Hesty, H. (2017). The Positive Deviance of Feeding Practices and Carring With Nutritional Status of Toddler Among Poor Families. Jurnal Kesehatan Masyarakat, 13(1), 106-112. Jurnal Kesehatan Masyarakat, 13(1), 106-112. doi.org/10.15294/kemas.v13i1.7919

Mubarak, 2018, Analisis Faktor yang Berhubungan dengan Status Gizi Anak Balita di Wilayah Pesisir Kecamatan Soropia, Jurnal Fakultas Kedokteran Universitas Halu Oleo, Volume 5 Nomor 2 Bulan April 2018 E-ISSN: 2443-0218, http://ojs.uho.ac.id/index.php/medula/arti cle/download/4368/3379

Muchlashin, A., \& Ansori, T. (2020). Sekolah Balita sebagai Upaya Pendampingan Pengentasan Gizi Buruk pada Balita di Kelurahan Bulak Banteng Surabaya. Amalee: Indonesian Journal of 
Community Research and

Engagement, 1(2), 113-123. https://doi.org/10.37680/amalee.v1i2.330

Notoatmodjo, S., 2012.Metodelogi Penelitian Kesehatan. Jakarta: Rineka Cipta.

Notoatmojo, 2012. Promosi Kesehatan dan Perilaku Kesehatan. Jakarta: Rineka Cipta.

Profil Dinas Kesehatan Kabupaten Nagan Raya, 2016. Rekapitulasi masalah gizi dan jumlah balita tahun 2012 sampai 2016.

Profil Kesehatan Aceh, 2014. Angka kejadian gizi baik dan buruk balita aceh. Di unduh tanggal 1 November 2015.

Putri, A. S. R., \& Mahmudiono, T. (2020). Efektivitas Pemberian Makanan Tambahan (PMT) Pemulihan Pada Status Gizi Balita di Wilayah Kerja Puskesmas Simomulyo, Surabaya. Amerta Nutrition, 4(1), 58. https://doi.org/10.20473/amnt.v4i1.2020. $58-64$

Riset Kesehaan Dasar, 2013. Data Angka prevalensi balita gizi buruk, gizi kurang dan gizi lebih di indonesia tahun 2013. Di unduh tanggal 1 November 2015.

Risna Melina Rumahorbo, Nurul syamsiah, M. (2020). Faktor-Faktor Yang Mempengaruhi Tumbuh Kembang Balita Di Wilayah Kerja Puskesmas Pancur Batu Kabupaten Deli Serdang Tahun 2019. Chmk Health Journal, 4(April), 158165.

Sampurno, M. B. T., Kusumandyoko, T. C., \& Islam, M. A. (2020). Budaya Media Sosial, Edukasi Masyarakat, dan Pandemi COVID19. SALAM: Jurnal Sosial Dan Budaya Syar-i, 7(5).

http://doi.org/10.15408/sjsbs.v7i5.15210

Sani, M., Solehati, T., \& Hendarwati, S. (2020). Hubungan usia ibu saat hamil dengan stunted pada balita 24-59 bulan. Holistik Jurnal Kesehatan, 13(4), 284-291.

https://doi.org/10.33024/hjk.v13i4.2016

Setiyaningrum, S. (2020). Hubungan pengetahuan dan sikap ibu keluarga sadar gizi dengan status gizi anak balita
1,2. JIGK (Jurnal IImiah Gizi

Kesehatan), 1(02), 33-40. Retrieved from http://jurnal.umus.ac.id/index.php/JIGK/a rticle/view/140

Shah, A. C., Sareen, D., \& Goyal, D. K. (2020). Clinical and demographic profile of paediatric patients presenting with acute diarrhea. International Journal of Contemporary Pediatrics, 7(5), 1043. https://doi.org/10.18203/23493291.ijcp20201635

Supariasa, dkk, 2012.Penilaian stantus gizi. Jakarta: EGC

Sutomo, A, 2010.Makanan Sehat Pendamping ASI.Jakarta : PT. Angromedia Pustaka

Syahmien, M, 2010. Perencanaan dan Pengembangan Sumber Daya Manusia. Jakarta: Rineka Cipta.

Tantri dan Julita, 2012.Hubungan Pengetahuan, Sikap, dan Tindakan Ibu dengan Status Gizi pada Balita Usia 1-5 Tahun di Kelurahan Watonea Wilayah Kerja Puskesmas Katobu Kabupaten Muna. Jurnal Kesehatan. Vol 1. No 2. ISSN : 2302-1721.

Vinda, 2012.IImu Gizi Dasar Kesehatan. Salemba Medika. Jakarta.

WHO (World Health Organization). Laporan Gizi Baik dan Buruk Indonesia 2012.Di unduh tanggal 1 November 2015.

Wijoyo, 2010.Pengantar Umum Prilaku Manusia. Graha Ilmu. Jakarta.

Wirda dan Ernawati, 2012.Hubungan Perilaku Keluarga Sadar Gizi dengan Status Gizi Balita Usia 12-59 Bulan di Wilayah Kerja Puskesmas Blangkejeren Kecamatan Blangkejeren Kabupaten Gayo Lues. Jurnal Gizi, Kesehatan Reproduksi dan Epidemiologi. Vol 2. No 2.

Zogara, A. U., \& Pantaleon, M. G. (2020). Faktor-faktor yang Berhubungan dengan Kejadian Stunting pada Balita. Jurnal IImu Kesehatan Masyarakat, 9(02), 85-92. https://doi.org/10.33221/jikm.v9i02.505 